\title{
Role of Corticosteroids in Reducing Postoperative Morbidity Following Removal of Impacted Wisdom Teeth: A Comparative Study
}

\author{
Namineni Kiran Kumar ${ }^{1}$,T. Murali Krishna ${ }^{2}$,Ch. Hima Silpa ${ }^{3}$ \\ Department Of Oral And Maxillofacial Surgery,Rajiv Gandhi Institute Of Medical Sciences, Ongole ,Prakasam \\ District ,Andhra Prdesh
}

\begin{abstract}
:
Background: The surgical removal of impacted third molar teeth can result in considerable pain, swelling and trismus. Pain and swelling can be reduced via the glucocorticoids and with nonsteroidal anti inflammatory drugs. . Quantifying the effectiveness of steroids has varied greatly among studies.

Objectives: To investigate the role of prophylactic preoperative steroids in reducing post operative morbidity in patients undergoing surgical removal of the wisdom tooth.

Methodology: Comparative study has been conducted with two different drug interventions and modalities on patients indicated for surgical removal of impacted third molar teeth. First Group patients received pre-operative Dexamethasone injection Ihour prior to the surgery and administered with analgesics and Metronidazole for 3 days. Second Group patients received only therapeutic oral medication posts operatively analgesic and Metronidazole for 3 days.

Results: Group I consisted of 30 patients, in which $76.7 \%$ were males and $23.3 \%$ were females and Group II was also consisted of 30 patients, in which $63.3 \%$ were males and $36.7 \%$ were females. The increase facial in swelling in Group II patients was statistically and clinically significant $(P<0.05)$. The difference in the levels of pain between the 2 groups at 24 hours and on $7^{\text {th }}$ post-operative day showed no statistical significance. The difference in $M B W$ between 2 groups at all the intervals was statistically and clinically significant $(P<0.001)$.

Conclusions: The use of single preoperative corticosteroid dosage appears to be useful in reducing postoperative edema and trismus following the removal of impacted third molars. A high dosing intramuscularly, shown significant and sustained anti-inflammatory effects with a single dose administrated preoperatively.
\end{abstract}

Keywords: Impacted teeth, Ward's Incision, Maximum Bite Width (MBW), Visual Analog Scale (VAS)

\section{Introduction}

The surgical removal of impacted third molar teeth can result in considerable pain, swelling and trismus ${ }^{1}$. By controlling the extent of the inflammatory process associated with the surgical procedure, these sequelae can be reduced. Factors contributing to post operative pain, edema and trismus are complex. Many modalities are used to abate post operative sequelae in third molar removal.

One such modality that has been proposed is the administration of corticosteroids, because they are potent anti inflammatory agents. The cycloxygenase and prostaglandins play a crucial role in development of post operative pain and swelling ${ }^{2}$. Pain and swelling can be reduced via the membranestabilizing anti exudative effect of glucocorticoids and by inhibiting cycloxygenase with nonsteroidal anti inflammatory drugs.

The use of steroid therapy to control the sequale of inflammation in the third molar surgery has been in use since its inception in the 1950's. The effectiveness of glucocorticoids as anti inflammatory agents was first reported by Philips Hench and Kendall in 1949, who used cortisone to treat rheumatoid arthritis ${ }^{3}$. The earliest published reports of glucocorticosteroids use in dentistry were by Spies etal in $1952^{4}$ and Stream and Horton in $1953^{5}$.

Even though these are numerous and generally support the use of steroids in exodontias, many suffer from methodological in consistencies that have compromised scientific conclusions. Quantifying the effectiveness of steroids has varied greatly among studies, with no optimal agent, dose or route being established ${ }^{6}$. The aim of this clinical study was to investigate the role of prophylactic preoperative steroids in reducing post operative morbidity in patients undergoing surgical removal of the wisdom tooth.

\section{Materials And Methods}

The study was conducted over period of six months from July 2015 to December 2015 in Department of Oral and Maxillofacial Surgery in Rajiv Gandhi Institute of Medical Sciences Ongole Prakasam Distirct of 
Andhra Pradesh. . Sixty healthy patients requiring removal of mandibular third molars are included in this study. They were randomly divided into 2 groups. To be part of a study, patients could have no list of indications to the use of corticosteroids and analgesics or local anaesthetic and no previous complications after steroid use.

All the teeth required Ward's incision for mucoperiosteal flap reflection and removal of surrounding bone in a clinically acceptable fashion with a rotary surgical hand piece under saline spray. Surgical time was recorded and post-surgical instructions were standardized for all patients. Patients were instructed to return 1st and $7^{\text {th }}$ post-operative day to evaluate post-operative sequale. Post-surgical sequale were measured in all patients by the same examiner for the sake of standardization. Data were collected preoperatively and post operatively on $1^{\text {st }}$ and 7 thdays. Post-operative parameters assessed in this study were swelling, pain and trismus.

Facial swelling was determined by recording facial size and comparing it with pre surgical baseline measurements made of the distances from the lateral corner of the eye to the angle of the mandible, from tragus to the outer corner of the mouth, and from tragus to the pogonion, by using thread (Figure-1).

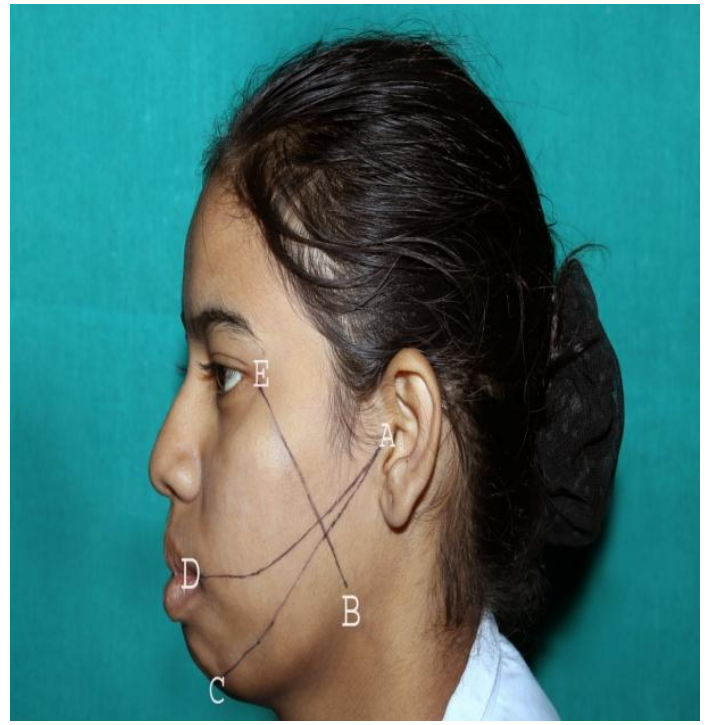

Fig:- Marking Used to Measure the Swelling

(A- Tragus of the Ear, B- Angle of the Mandible , C- Pogonion, D- Corner of the Mouth, E- Lateral Canthus of the Eye)

The pain assessed on pain assessment scale consist of $10 \mathrm{~cm}$ long horizontal visual analog scale (V A S) with $0=$ No pain $10=$ intolerable pain recorded by patients. To assess the effect of the medication on the extent of post-operative trismus, maximal mouth opening was measured as the maximum bite width (MBW) pre operatively and $1^{\text {st }}$ and $7^{\text {th }}$ post-operative day. Measurements are averaged and recorded. Other factors evaluated were wound dehiscence, dry socket, infection and bleeding ${ }^{7}$.

Two groups were formed, Group - I: (Group A) received pre-operative $8 \mathrm{mg}$ Dexamethasone submucosal injection -1hour prior to the surgery. In addition to this each patient receives analgesic (Ibuprofen $400 \mathrm{mg}$ and paracetamol 500mg combination) and metronidazole $400 \mathrm{mg} 8^{\text {th }}$ hourly for 3 days. Group - II: (Group B) each patient received only therapeutic oral medication posts operatively analgesic (Ibuprofen $400 \mathrm{mg}$ and paracetomol $500 \mathrm{mg}$ combination) and $400 \mathrm{mg}$ of metronidazole $-8^{\text {th }}$ hourly for 3 days.

The collected data was stored safely in form of hard copies and also electronically. Data was analyzed by using the excel and also EPI- INFO of CDC Atlanta. Intially descriptive statistics techniques were carried out later on the test t-student and test was used to compare the different groups.. The level of significance used in the statistical decisions was of $5,0 \%$.

\section{Results}

A total of 60 patients participated in the study, with patients aged between 18 to 52 years. Patients were randomly categorized into 2 groups, Group A and Group B. Group A consisted of 30 patients, in which 23 males $(76.7 \%)$ and 7 females $(23.3 \%)$ with a mean age of $27.37 \pm 6.15$ years. Group B consisted of 30 patients, in which 19 males $(63.3 \%)$ and 11 females $(36.7 \%)$ with a mean age of $28.93 \pm 7.33$ years (Table-1). 
Table-1: Distribution of Patients According to Age and Sex

\begin{tabular}{|c|c|c|c|c|c|c|}
\hline & \multicolumn{3}{|c|}{ GROUP A } & \multicolumn{3}{c|}{ GROUP B } \\
\hline AGE (Year) & Male & Female & Total & Male & Female & Total \\
\hline$<25$ & $11(47.8)$ & $3(42.9)$ & $14(46.7)$ & $9(47.4)$ & $2(18.2)$ & $11(36.7)$ \\
\hline $26-35$ & $10(43.5)$ & $4(57.1)$ & $14(46.7)$ & $9(47.4)$ & $8(72.7)$ & $17(56.7)$ \\
\hline $\begin{array}{c}36 \text { and } \\
\text { above }\end{array}$ & $2(8.7)$ & - & $2(6.7)$ & $1(5.3)$ & $1(9.1)$ & $2(6.7)$ \\
\hline Total & $23(76.7)$ & $7(23.3)$ & $30(100)$ & $19(63.3)$ & $11(36.7)$ & $30(100)$ \\
\hline Mean & \multicolumn{7}{|c|}{27.37} & & 3.93 \\
\hline S D & 6.1503 & & 3294 \\
\hline
\end{tabular}

The difference in duration of surgical procedures between the two groups on the mean value was 2 minutes, with a mean time of 26 minutes (standard deviation - 6.8 minutes) in group A and 24 minutes (Standard deviation 6.9 minutes) in Group B (Table-2).

Table-2: Duration of Surgery in Minutes

\begin{tabular}{|c|c|c|c|}
\hline Group & Mean & Standard Deviation & Range \\
\hline Group-A & 26.77 & 6.80 & $12-45$ \\
\hline Group-B & 24.37 & 6.90 & $15-42$ \\
\hline
\end{tabular}

As compared to the preoperative base line measurement, a significant difference in swelling was observed. (Table -3). The mean preoperative tape measurements of patients in Group A and B are 12.04 and $11.92 \mathrm{~cm}$ respectively.

Table-3: Post Operative Changes Swelling Comparison Between Group A and Group B

\begin{tabular}{|c|c|c|c|c|c|c|c|c|c|c|}
\hline & \multicolumn{4}{|c|}{ Group-A } & \multicolumn{4}{|c|}{ Group-B } & \multirow[b]{2}{*}{$\begin{array}{c}\text { Differ- } \\
\text { ence } \\
\text { bet- } \\
\text { ween A } \\
\text { \& B }\end{array}$} & \multirow[b]{2}{*}{$\begin{array}{c}\text { Signifi- } \\
\text { cance }\end{array}$} \\
\hline $\begin{array}{l}\text { Time of } \\
\text { asse- } \\
\text { ssment }\end{array}$ & $\begin{array}{c}\text { Mean } \\
+-\end{array}$ & S.D & $\begin{array}{c}\text { Differ- } \\
\text { ence } \\
\text { from } \\
\text { base } \\
\text { line }\end{array}$ & $\begin{array}{l}\text { Signifi- } \\
\text { cance }\end{array}$ & Mean & +- S.D & $\begin{array}{c}\text { Differ- } \\
\text { ence } \\
\text { from } \\
\text { Base } \\
\text { Line }\end{array}$ & $\begin{array}{c}\text { Signifi- } \\
\text { cance }\end{array}$ & & \\
\hline Pre OP & 12.0422 & .05 & - & - & 11.92 & .69 & - & - & .12 & N.S. \\
\hline $24 \mathrm{Hrs}$ & 12.01 & .51 & 0.03 & N.S. & 12.40 & .70 & .47 & $\mathrm{P}<0.001$ & .44 & $\mathrm{P}<0.01$ \\
\hline $7^{\text {th }}$ Day & 11.86 & .48 & 0.18 & $\mathrm{P}<0.001$ & 12.03 & .64 & 0.11 & $\mathrm{P}<0.05$ & .07 & N.S. \\
\hline
\end{tabular}

*Values In Cms

On the first postoperative day, the sum of the tape measurement in group A showed no difference in facial swelling (mean $12.01 \mathrm{~cm}$ ) and facial swelling was observed to normal base line measurement (mean 11.86 $\mathrm{cm})$ at $7^{\text {th }}$ post-operative day. On comparison with the patient in Group B. Showed at 24 hours (mean $\left.12.4 \mathrm{~cm}\right)$ and at $7^{\text {th }}$ post-operative day (mean $12.03 \mathrm{~cm}$ ). The increase facial in swelling in Group B patients was statistically and clinically significant $(\mathrm{P}<0.05)$. However the difference between Group A and Group B is $0.44 \mathrm{~cm}$, although statistically significant seems to be insignificant clinically at 24 hours and at $7^{\text {th }}$ post-operative day, swelling in not statically significant (0.7).

When postoperative trismus, was considered maximal mouth opening was measured as the maximum bite width (MBW) preoperatively, at 24 hours and 7 days post operatively (Table 4). By contrast with preoperative $\mathrm{MBW}$ of $45 \mathrm{~mm}$ in Group $\mathrm{A}$ and $42.50 \mathrm{~mm}$ in Group B, on the first post-operative day a mean reduction in the MBW to $32.57 \mathrm{~mm}$ in Group A and a significant reduction to 22.67 was seen in the B group respectively. At $7^{\text {th }}$ day, the MBW was $40.93 \mathrm{~mm}$ and $32.23 \mathrm{~mm}$ in group A and B. The difference in MBW between 2 groups at all the intervals was statistically and clinically significant $(\mathrm{P}<0.001)$.

Table-4: Post Operative Changes in Mouth Opening Comparison Between Group A and Group B

\begin{tabular}{|c|c|c|c|c|c|c|c|c|c|c|}
\hline & \multicolumn{4}{|c|}{ Group-A } & \multicolumn{4}{|c|}{ Group-B } & \multirow[b]{2}{*}{$\begin{array}{c}\text { Differ- } \\
\text { ence } \\
\text { bet- } \\
\text { ween A } \\
\text { \& B }\end{array}$} & \multirow[b]{2}{*}{$\begin{array}{l}\text { Signifi- } \\
\text { cance }\end{array}$} \\
\hline $\begin{array}{c}\text { Time } \\
\text { of asse- } \\
\text { ssment }\end{array}$ & $\begin{array}{c}\text { Mean } \\
+-\end{array}$ & S.D & $\begin{array}{l}\text { Differ- } \\
\text { ence } \\
\text { from } \\
\text { base } \\
\text { line } \\
\end{array}$ & $\begin{array}{l}\text { Signifi- } \\
\text { cance }\end{array}$ & Mean & $\begin{array}{l}+- \\
\text { S.D }\end{array}$ & $\begin{array}{c}\text { Differ- } \\
\text { ence } \\
\text { from } \\
\text { Base } \\
\text { Line }\end{array}$ & $\begin{array}{l}\text { Signifi- } \\
\text { cance }\end{array}$ & & \\
\hline Pre OP & 45.0 & 7.47 & - & - & 42.50 & 7.02 & - & - & 2.5 & N.S. \\
\hline $24 \mathrm{Hrs}$ & 32.57 & 8.55 & 12.43 & $\mathrm{P}<0.001$ & 22.67 & 7.25 & 19.83 & $\mathrm{P}<0.001$ & 7.4 & $\mathrm{P}<0.001$ \\
\hline $7^{\text {th }}$ Day & 40.93 & 8.40 & 4.07 & $\mathrm{P}<0.01$ & 32.23 & 7.74 & 10.27 & $\mathrm{P}<0.001$ & 6.2 & $\mathrm{P}<0.001$ \\
\hline
\end{tabular}

*Values In Mm

Pain as measured by VAS (Table -5) showed 27 patients with mild pain in group A and 22 patients in group B at 24 hours. One patient in each group experienced severe pain at 24 hours. At the $7^{\text {th }}$ post-operative 
day all the patients in group A (30) and 29 patients in group B experienced mild pain and one patient experienced moderate pain in Group B.

Table-5: Pain Assessment Comparison Between Group A and Group B

\begin{tabular}{|c|c|c|c|c|c|c|}
\hline & \multicolumn{2}{|c|}{ BASE } & \multicolumn{2}{|c|}{$1 \mathrm{DAY}$} & \multicolumn{2}{|c|}{$7 \mathrm{DAY}$} \\
\hline & Group A & Group B & Group A & Group B & Group A & Group B \\
\hline No Pain & - & - & - & - & - & - \\
\hline Mild & $19(63.3)$ & $18(60.0)$ & $27(90.0)$ & $22(73.3)$ & $30(100)$ & $29(96.7)$ \\
\hline Moderate & 11(36.7) & $9(30.0)$ & $2(6.7)$ & $7(23.3)$ & - & $1(3.3)$ \\
\hline Severe & - & $3(10.0)$ & 1(3.3) & $1(3.3)$ & - & - \\
\hline $\begin{array}{c}\text { Not } \\
\text { Tolerable }\end{array}$ & - & - & - & - & - & - \\
\hline & $\alpha 2=3.23$ (N.S) & & $\alpha 2=3.29$ (N.S) & & $\alpha 2=1.01($ N.S $)$ & \\
\hline
\end{tabular}

However the difference in the levels of pain between the 2 groups at 24 hours and on $7^{\text {th }}$ post-operative day showed no statistical significance. The rate of post-operative complication like infection, wound dehiscence and alveolar osteitis for the both the groups remained none.

\section{Discussion}

The surgical removal of impacted mandibular third molars can lead to inflammatory reactions like pain, swelling and trismus in the facial soft tissues. This has led to the extensive use of a variety of medication to control these post-operative sequelae. Corticosteroids are potent inhibitors of inflammation, and they have been widely used in different routes and regimens to lessen the inflammatory sequelae after third molar surgery. The primary mechanisms are thought to involve suppression of the leukocytes and macrophages accumulation at the site of inflammation and prevention of prostaglandin formation.

Many clinical trials have been carried out to determine the efficacy of steroids on lessening the postsurgical sequelae of third molar removal. In 1969 Hooley and Francis ${ }^{8}$ reported the use of oral betamethasone for reduction of swelling, trismus and pain. In 1975, Eugene, Messer and Keller ${ }^{9}$ reported that use of dexamethasone, $4 \mathrm{mg}$ injected into the masseter muscle, after third molar extraction, proved to be of great value in reducing edema. In 1985, Anne Pedersen ${ }^{10}$ used Decadron phosphate in the relief of complaints after third molar surgery. The greatest concern about the use of steroids in third molar surgery is suppression of the hypothalamus - pituitary adrenal axis (HPA). However, the literature indicates that short term; high-dose steroids do not significantly impair the HPA. Williamson et al found that HPA axis was altered by a single 8mg dose of dexamethasone, but cortisol secretion was restored within 7 days.

S.Schultze-Mosgau et al ${ }^{11}$ in a prospective intra individual, randomized, double blind investigation, showed combination of ibuprofen and methylprednisolone has good analgesic and anti-inflammatory action. E. Novak et al ${ }^{12}$ in a double blind investigation showed that a single dose of methylprednisolone $(30 \mathrm{mg} / \mathrm{kg})$ resulted in no serious side effects and could, therefore, be considered safe for use. Evaluation of facial swelling has proven to be most problematic. Swelling involves a 3 dimensional volumetric change at the tissue and cellular level. Various methods used to document soft tissue swelling are photographs, stereo photographs, cubic spline method, face-bows, ultrasound, magnetic resonance imaging and C.T scan. No technique has proved superior (or) more accurate in analyzing swelling. A linear measurement which seems to be reliable and low cost technique was chosen for this study.

Results from this study showed significant differences in facial swelling and trismus between the two groups. Patient who received a prophylactic steroid dosing showed an improvement in the clinical parameters, like swelling and trismus at $1^{\text {st }}$ postoperative day. (Table III, IV). The increase in swelling in group B where patients had not received any prophylactic steroids was seen. On the $7^{\text {th }}$ postoperative day, the difference in swelling between the two groups was not significant. Bierne and Holland ${ }^{13}$ compared different dosage regimen of corticosteroids in third molar surgery and concluded that administration of $125 \mathrm{mg}$ of methylprednisolone was effective in reduction of postoperative oedema without any significant side effect. Trismus (MBW) observed significant difference at all intervals i.e. on $1^{\text {st }}$ and $7^{\text {th }}$ postoperative day. On comparison between the two groups, there was dramatic difference between the two groups. Although there was no significant difference in the pain parameter.

No complications like infection, wound dehiscence, dry socket were seen in both the groups. Healing was satisfactory in all cases. Corticosteroids are thought to reduce healing rate when administered for prolonged periods. Lisa Gersema et al ${ }^{14}$ demonstrated that when corticosteroids administered for less than 3 days does not increase risk for delayed wound healing. Peterson et al ${ }^{15}$ advocated the use of corticosteroids to help minimize pain, swelling and trismus. Esen et al ${ }^{16}$ found that administration of $125 \mathrm{mg}$ of methylprednisolone does not have any significant effect on postoperative infections, disturbance of wound healing, adrenal suppression and other corticosteroid-related complications ${ }^{16}$. 
A study by Jose Rodrigues Laureano Filho etal ${ }^{17}$ revealed The administration of dexamethasone 1 hour preoperatively, combined with the postoperative administration of $750 \mathrm{mg}$ of paracetamol on the day of the operation and the 4 postoperative days, produced a clear reduction in postoperative pain and cheek swelling after impacted third molar removal. In 2005 Tiwana et al ${ }^{18}$ reported that the administration of IV corticosteroids before third molar surgery offers a beneficial effect on health-related quality of life, we agreed with this, because having swelling and pain less the patient can return to his normal life.

Well controlled studies using a combination of glucocorticosteroids, non-steroidal anti-inflammatory drugs, and long acting local anesthetics are needed to establish a protocol for maximum effectiveness in reducing post-surgical discomfort in impacted third molar removal.

\section{Summary And Conclusions}

Based on this study, the use of single preoperative corticosteroid dosage appears to be useful in reducing post-operative edema and trismus following the removal of impacted third molars. In this study, a dose of $8 \mathrm{mg}$ dexamethasone was chosen because of its higher potency, lower sodium-retaining ability and longer half-life. A high dosing intramuscularly, shown significant and sustained anti-inflammatory effects with a single dose administrated preoperatively. The acetates of glucocorticosteroids are relatively insoluble in water and can be administered only intramascular to provide for a slow absorption and a prolonged duration of effect.

However, good understanding of the physiological and pharmacologic effects and contra-indications to the use of steroids is mandatory. Evaluation of facial swelling resulting from surgical removal of impacted third molars has proven to be most problematic. So more accurate means of measuring post-operative swelling needs to be developed for accurate quantification.

\section{References}

[1]. Jay W, Fried Man DDS. The prophylactic extraction of third molar: A Public Health Hazard. Am J Public Health. 2007 September; 97 (9): 1554-1559.

[2]. Daniel E, Becker DDS. Pain Management: Part.I Managing and Post Operative Dental Pain. Anesthesia Progress.2010 57 (2): 6769.

[3]. Hench PS, Kendall EC, Slocum CH, Poley HF. Effect of Cortisone acetate and priotity ACTH on rheumatoid arthritis, Rheumatic fever and certain other conditions. A study in clinical Psychology Arch Intern Med. 545-546.

[4]. Spies TD, Dreizens, Stone RE, Garcia- Lopez G, Lopez- TOC R, Reboredo A. Clinical Appraisal of ACTH and cortisone as therapeutic agent in dental Medicine. Oral Sur Oral Medi Oral Patl. 1952; 19525:25-40.

[5]. Stream L, Harton G: Hydrocortisoe in Dental Practice. Dent Diag 1953 ;49: 8

[6]. Luyk NH, Anderson J, Ward Booth RP. Corticosteroid therapy in dental patients. Br Dent J 1985; 159: 12-17.

[7]. Dauptin AP etal. Bias and precison in visual analogue scales. A randomized controlled trial. American Journal of Epidemiology . 1999; 150 (10): 1117-1127.

[8]. Hooley JR, Francis FHBetamethasone in traumatic oral surgery. J Oral Surg. 1969 Jun;27(6): 398-403.

[9]. Eugene J. Messer, J.J. Kellar, G. Lakes: The use of intra oral Dexamethasone after extraction of mandibular third molars. Oral surgery: 1975:40:594-597.

[10]. Anne Pedersen: -Decadron phosphate in the relief of complaints after third molar surgery. A double blind, controlled trial with bilateral oral surgery. Int.J.Oral surgery: 1985:14:235-240.

[11]. S. Schultze-Mosgau, R. Schmelzeisen, J.C. Frolich and H. Schmele: Use of ibuprofen and methylprednisolone for the prevention of pain and swelling after removal of impacted third molars. J. Oral and maxillofacial surg: 1995,53:2-7.

[12]. E.Novak, S.S. Stubbs, C.E. Seckman and M.S. Hearson: Effects of a single large intravenous dose of methylprednisolone sodium succinate; clinical pharmacology and therapeutics: 711-717, 1970.

[13]. Bierne RO, Hollander B. The effect ofmethylprednisolone on pain, trismus and swelling after removal of third molars. Oral Surg Oral Med Oral Pathol Oral Radiol Endod 1986; 61: 134-138

[14]. Lisa Gersema and Karen Baker. Use of corticosteroids in Oral surgery. J Oral and maxillofacial surgery: 1992, March: 50 270-277

[15]. Peterson LJ, Ellis E, Hupp J, Tucker M. Comtemporary Oral and Maxillofacial Surgery (2nded.) Mosby 1993; pp.225-260

[16]. Esen E, Tasar F, Akhan O. Determination of the anti-inflammatory effects of methylprednisolone on the sequelae of third molar surgery. J Oral Maxillofac Surg 1999; 57(10):1201-1206.

[17]. Jose Rodrigues L F, Paul E M , Marvis A, Milane C , Caio F . Clinical comparative study of the effectiveness of two dosages of Dexamethasone to control postoperative swelling, trismus and pain after the surgical extraction of mandibular impacted third molars. Med Oral Patol Oral Cir Bucal. 2008 Feb1;13(2):E129-32.

[18]. Tiwana PS, Foy SP, Shugars DA, Marciani RD, Conrad SM, Phillips C, et al. The impact of intravenous corticosteroids with third molar surgery in patients at high risk for delayed health-related quality of life and clinical recovery. J Oral Maxillofac Surg. 2005 Jan;63(1):55-62. 